\title{
Cell Autonomous Dysfunction and Insulin Resistance in Pancreatic $\alpha$ Cells
}

\author{
Norikiyo Honzawa ${ }^{1,2}$, Kei Fujimoto ${ }^{1, *}$ and Tadahiro Kitamura ${ }^{2}$ \\ 1 Division of Diabetes, Metabolism and Endocrinology, Department of Internal Medicine, Jikei University \\ School of Medicine, 3-25-8 Nishishinbashi, Minato-ku, Tokyo 105-8461, Japan \\ 2 Metabolic Signal Research Center, Institute for Molecular and Cellular Regulation, Gunma University, \\ 3-39-15 Showa-machi, Maebashi, Gunma 371-8512, Japan \\ * Correspondence: fuji@jikei.ac.jp; Tel.: +81-03-3433-1111; Fax: +81-3-3578-9753
}

Received: 29 June 2019; Accepted: 26 July 2019; Published: 28 July 2019

check for updates

\begin{abstract}
To date, type 2 diabetes is considered to be a "bi-hormonal disorder" rather than an "insulin-centric disorder," suggesting that glucagon is as important as insulin. Although glucagon increases hepatic glucose production and blood glucose levels, paradoxical glucagon hypersecretion is observed in diabetes. Recently, insulin resistance in pancreatic $\alpha$ cells has been proposed to be associated with glucagon dysregulation. Moreover, cell autonomous dysfunction of $\alpha$ cells is involved in the etiology of diabetes. In this review, we summarize the current knowledge about the physiological and pathological roles of glucagon.
\end{abstract}

Keywords: pancreatic $\alpha$ cells; insulin resistance; glucagon

\section{Physiological Roles of Pancreatic Islet Hormones on Glucose Metabolism}

Neuronal and hormonal factors in the body strictly control blood glucose levels. The development of diabetes is attributed to the breakdown of the blood glucose control mechanism [1]. In 1921, Banting and Best discovered insulin, a hormone that lowers blood glucose levels in the body [2]. Insulin is secreted from pancreatic $\beta$ cells and binds to insulin receptors (IRs) in classical insulin target organs, such as the liver, adipose tissue, and skeletal muscle [3]. In the adipose tissue and skeletal muscle, glucose transporter (GLUT) 4 translocate from cytosol to the outer membrane via the phosphatidylinositol-3 kinase/protein kinase B (PI3K/Akt) pathway-dependent manner, which is a downstream signaling pathway of IR. Therefore, insulin promotes glucose uptake in these cells via GLUT4, thus resulting in a decrease in blood glucose levels [4]. Conversely, both GLUT2 and GLUT4 are involved in glucose uptake in the liver [5].

In 1923, Kimball and Murlin discovered glucagon from pancreas [6]. Glucagon is a polypeptide hormone comprising 29 amino acids, with a molecular weight of $3485 \mathrm{Da}$; it is secreted from $\alpha$ cells in the pancreatic islets of Langerhans but is also partially secreted from endocrine cells in the stomach and intestine. The primary physiological actions of glucagon are glycogenolysis, gluconeogenesis, and amino acid metabolism. After glucagon binds to glucagon receptors (GRs) in the liver, the acetylation of the cyclic adenosine monophosphate response element binding protein-regulated transcription coactivator (CRTC)2 and forkhead box protein O (FOXO)1 induce the expression of phosphoenolpyruvate carboxykinase (PEPCK) and glucose 6-phosphatase(G6-Pase) the rate-limiting enzymes of gluconeogenesis to promote gluconeogenesis while suppressing glycolysis [7-9]. Furthermore, glucagon promotes the degradation of glycogen to glucose by enhancing the phosphorylation of glycogen phosphorylase (GPase) via the cyclic adenosine monophosphate-protein kinase A (cAMP-PKA) pathway (glycogenolysis), thereby increasing the blood glucose levels [9]. Conversely, glucocorticoids increase blood glucose levels by promoting 
the glycation of proteins (deamination group) in the muscle cells and gluconeogenesis in the liver. Moreover, pancreatic islet hormones, such as somatostatin (secreted from pancreatic $\delta$ cells), pancreatic polypeptide (secreted from pancreatic polypeptide cells), and ghrelin (secreted from pancreatic $\varepsilon$ cells), play a role in metabolic homeostasis, including blood glucose regulation. In healthy individuals, these hormones accurately regulate the blood glucose level at 90-120 mg/dL. The dysregulation of these hormones is involved in the onset and exacerbation of diabetes.

\section{Cell Autonomous Dysfunction and Insulin Resistance in Pancreatic $\alpha$ Cells}

Type 2 diabetes is caused by relative insulin hyposecretion and insulin resistance. In particular, decreased insulin secretion due to reduced pancreatic $\beta$ cell mass is considered the leading cause of the onset and exacerbation of diabetes. However, in recent years, it has been surprisingly reported that the administration of streptozotocin (STZ), which destroys $\beta$ cells and completely inhibits insulin secretion, does not increase blood glucose levels in glucagon deficient mice [10]. When STZ was administered to glucagon receptor-deficient mice, the blood glucose levels remain normal even when insulin secretion is suppressed [11]. Furthermore, it has been shown that blood glucose levels increase when a glucagon receptor is transiently introduced into the liver of glucagon receptor-deficient mice treated with STZ [12]. These reports indicate that glucagon plays a more important role than insulin in increasing blood glucose levels and support the "glucagonocentric hypothesis" proposed in 2012 [13]. That is, glucagon and GRs have extremely important roles in the glucose intolerance in diabetes, and the glucagon pathway as therapeutic targets has attracted attention.

In vivo, glucagon secretion from the pancreatic $\alpha$ cells is strictly controlled by insulin $[14,15]$. Furthermore, in type 2 diabetes patients, insulin resistance is observed in the liver, muscle, and adipose tissue, which are the classical insulin target organs. In recent years, insulin resistance in different organs in the body has also been proposed. Assuming that such insulin-resistant state is also present in pancreatic $\alpha$ cells, it is expected that insulin will not suppress glucagon secretion and that glucose tolerance will further aggravate (Figure 1). Therefore, identifying the regulatory mechanism of glucagon secretion and insulin resistance in pancreatic $\alpha$ cells can contribute to the elucidation of the pathophysiology of diabetes.

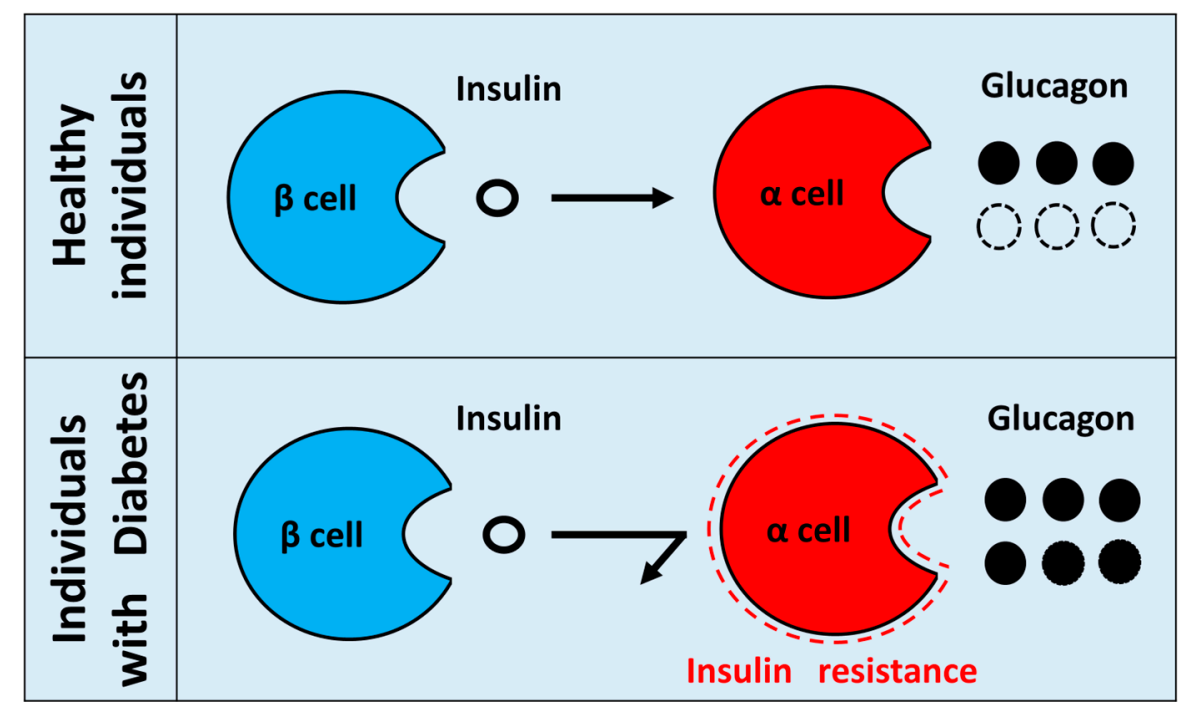

Figure 1. Hypothesis of insulin resistance regulating glucagon secretion in pancreatic $\alpha$ cells. In healthy individuals, insulin from pancreatic $\beta$ cells regulates glucagon secretion from pancreatic $\alpha$ cells. By contrast, when insulin resistance exists in diabetic pancreatic $\alpha$ cells, insulin can no longer suppress glucagon secretion from $\alpha$ cells, which results in hypersecretion of glucagon. Hypothetical paradoxical glucagon hypersecretion observed in diabetes. 


\subsection{Glucose-Regulated Glucagon Secretion in $\alpha$ Cells (Cell Autonomous)}

When the blood glucose level deviates from the normal level, either hypoglycemia or hyperglycemia occurs. When healthy individuals are subjected to fasting, insulin secretion from $\beta$ cells is suppressed, whereas glucagon secretion from $\alpha$ cells is enhanced. By contrast, opposite changes are expected to occur when healthy individuals are fed. However, in patients with diabetes, a paradoxical glucagon hypersecretion occurs despite the presence of hyperglycemia. The most important factor affecting glucagon secretion in healthy individuals is glucose per se. Several glucose transporters, including GLUT1, sodium glucose co-transporter (SGLT1), and SGLT2, are expressed in human pancreatic $\alpha$ cells [16-19]. However, we recently reported that only SGLT1, not SGLT2, is expressed in both human and mouse pancreatic $\alpha$ cells [20]. In pancreatic $\alpha$ cells, glucose uptake occurs via the aforementioned GLUT, and the adenosine triphosphate (ATP)/adenosone diphosphate ratio increases via ATP production during glycolysis and tricarboxylic acid cycle (TCA cycle). In addition, ATP depolarizes $\mathrm{K}_{\mathrm{ATP}}$ channels and reduces glucagon secretion [21]. ATP depolarizes $\mathrm{K}_{\mathrm{ATP}}$ channels resulting in the influx of $\mathrm{Na}^{+}$from $\mathrm{Na}^{+}$channels, followed by $\mathrm{Ca}^{2+}$ influx via P/Q-type $\mathrm{Ca}^{2+}$ channels [22]. Although $\mathrm{Ca}^{2+}$ is the main trigger of glucagon secretion, under conditions where glucose strongly suppresses glucagon secretion in isolated islets, the $\mathrm{Ca}^{2+}$ signal is only moderately or temporarily decreased [23]. In addition, it has been reported that hypoglycemia stimulates glucagon secretion by directly elevating cyclic adenosine monophosphate (cAMP) concentrations regardless of $\mathrm{Ca}^{2+}$ signaling [24]. That is, these reports indicate that glucagon secretion is affected by various factors, and that $\mathrm{Ca}^{2+}$ and cAMP are only sufficient regulators for glucagon secretion. Under high glucose conditions, an SGLT-dependent increase in the intracellular $\mathrm{Na}^{+}$concentration and a decrease in the mitochondrial $\mathrm{pH}$ increase glucagon secretion via the $\mathrm{K}_{\mathrm{ATP}}$ channels [25]. These phenomena may partially explain the paradoxical glucagon hypersecretion in diabetes. As previously mentioned, several researchers have recently reported about the molecular mechanism of glucose-regulated glucagon secretion from pancreatic $\alpha$ cells, but such mechanism has not been fully elucidated yet. The mechanism is believed to involve $\mathrm{K}_{\text {ATP }}$ channels, such as insulin secretion and the cAMP-PKA signal. However, such a result must be validated in future studies.

\subsection{Insulin Resistance in Pancreatic $\alpha$ Cells}

In diabetes, paradoxical glucagon hypersecretion occurs despite the presence of hyperglycemia, and glucagon hyposecretion occurs despite the presence of hypoglycemia [26-28]. These phenomena lead to the worse of blood glucose and prolonged hypoglycemia. The pathologies indicate the dysfunction of pancreatic $\alpha$ cells and can be partially explained by insulin resistance in pancreatic $\alpha$ cells.

In general, insulin resistance is a condition in which classical insulin target organs have decreased insulin sensitivity resulting in decrease of glucose uptake [29]. Increased insulin resistance impairs the IR downstream signaling pathway, accompanied with decreased glucose uptake in the cells and increased blood glucose levels. Insulin is involved in blood glucose levels by glucose uptake in classical insulin target organ such as liver, adipose tissue and muscle. Insulin is also involved in blood sugar levels by suppressing glucagon secretion in pancreatic $\alpha$ cells. In a study of pancreatic perfusion, the administration of insulin suppressed glucagon secretion in dogs with alloxan-induced diabetes and in rats with STZ-induced diabetes [30]. Furthermore, the addition of insulin antibodies to human islets has resulted in the increase in glucagon secretion, and in sulfonylurea receptor (SUR)1 knockout mice that lack glucose-induced insulin secretion, glucagon secretion under high glucose conditions was not suppressed [31]. However, SUR1 is also expressed in pancreatic $\alpha$ cells and involved in glucagon secretion via activation of $\mathrm{N}$-type $\mathrm{Ca}^{2+}$ channel [31]. This mechanism may also be involved in the enhancement of glucagon secretion in SUR1 knockout mice. Therefore, these reports have indicated that insulin suppress glucagon secretion. This effect may be mediated directly via the insulin receptor in $\alpha$ cells or indirectly via an increase in somatostatin secretion from pancreatic $\delta$ cells [32]. Insulin binds to the IR of $\alpha$ cells, inhibits the intracellular cAMP-PKA pathway, and reduces glucagon secretion in $\alpha$ 
cells [33]. In addition, some reports have shown that the sensitivity of $\mathrm{K}_{\mathrm{ATP}}$ channels is reduced via PI3K, which is a signal molecule downstream of IR, to suppress glucagon secretion [34,35]. In addition, IR downstream Akt is involved in gamma-aminobutyric acid (GABA) receptor translocation to the cell membrane [36]. Therefore, the molecular mechanism underlying the suppression of glucagon secretion by insulin has been elucidated (Figure 2).

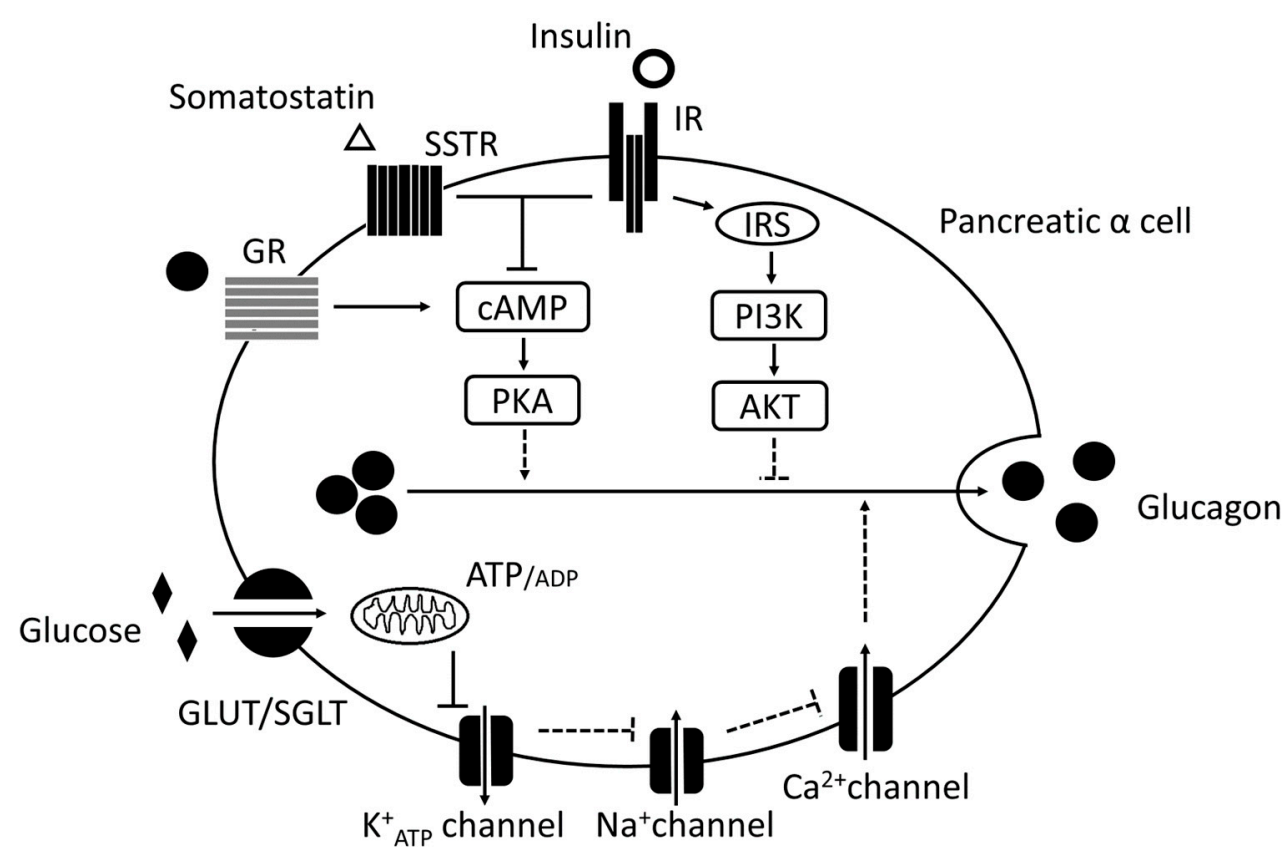

Figure 2. Hypothesis of the molecular mechanisms in pancreatic $\alpha$ cells. In pancreatic $\alpha$ cells, glucose translocates via glucose transporters, such as GLUT or SGLT. Glucose suppresses glucagon secretion via adenosine triphosphate (ATP) production in the glycolytic and tricarboxylic acid cycle. $\mathrm{K}^{+} \mathrm{ATP}, \mathrm{Na}^{+}$, and $\mathrm{Ca}^{2+}$ channels are involved in this molecular mechanism. Moreover, insulin suppresses glucagon secretion via IR, IRS, PI3K, and Akt. Somatostatin suppresses glucagon secretion via somatostatin receptor (SSTR) and CAMP-PKA pathways. Glucagon enhances glucagon secretion via glucagon receptor (GR) per se and cAMP-PKA pathways. Solid arrow: canonical positive signal, dotted arrow: hypothetical positive signal, solid $\mathrm{T}$ arrow: canonical negative signal, dotted $\mathrm{T}$ arrow: hypothetical negative signal.

In diabetic state, insulin resistance might exist in pancreatic $\alpha$ cells. If insulin resistance is present in pancreatic $\alpha$ cells, these insulin signals are attenuated and affect glucagon secretion. In fact, studies of pancreatic $\alpha$-cell-specific IR knockout mice have shown increased glucose and plasma glucagon levels ad libitum fed [15]. Furthermore, in the same mouse, impaired glucagon secretion during hypoglycemia was observed, and it partially mimics the phenomenon of diabetes [15]. In in vitro studies of glucagon secretion, rat-derived InR1G and mouse-derived $\alpha \mathrm{TC} 1$ glucagonoma cell lines are commonly used. When InR1G cells are cultured for a long time under high glucose conditions, glucagon secretion and glucagon mRNA expression are enhanced based on glucose levels [37]. In addition, in the same cells, insulin reduces preproglucagon (PPG) mRNA expression [38]. However, in the presence of ceramide, which induces lipid toxicity, the insulin-induced decrease in PPG mRNA expression is inhibited [38]. Moreover, glucagon secretion is suppressed by insulin using $\alpha \mathrm{TC} 1$ cells. By contrast, insulin did not suppress glucagon secretion in the presence of palmitic acid, which induces lipid toxicity [39]. Under such conditions, the phosphorylation of insulin receptor substrate (IRS), PI3K, and Akt, which are the downstream of IR, are suppressed, whereas the expression of paired box (PAX) 6 , a key transcription factor of proglucagon gene, is enhanced via mitogen-activated protein kinase (P-38) and extracellular signal-regulated kinase (ERK) 44/42 pathways [39]. These reports indicate the glucagon paradoxical hypersecretion in diabetic state including lipotoxic condition. Furthermore, 
the knockdown of IR in $\alpha \mathrm{TC} 1$ cells reduced glucagon secretion under low glucose conditions [40], which indicates that glucagon hyposecretion and hypoglycemia are prolonged in diabetic state. However, the increased glucagon secretion in hypoglycemia is mainly related to the sympathetic nerve. Pancreatic $\alpha$-cell-specific IR knockout mice have shown the reduced norepinephrine response at basal and hypoglycemic conditions, suggesting interactions between hypoglycemia and sympathetic nerves under post insulin receptor signaling [41]. In addition, we need to consider the interactions among islet cells under hypoglycemic conditions. Therefore, the mechanism by which glucagon secretion is reduced in hypoglycemia is still controversial, although it may be partially explained by insulin resistance in pancreatic $\alpha$ cells.

\section{Other Islet Cell Factors Regulating Glucagon Secretion}

Paracrine signaling indicates that secretion from cells does not act on distant cells through the general circulation but acts on adjacent cells via direct diffusion and other similar mechanisms. In rodent islets, $\beta$ cells are found in the center of the islet and $\alpha$ cells around the islets. Anatomically, paracrine factors from $\beta$ cells may affect $\alpha$ cells, considering that blood flows from the central to the peripheral part in the islet [42]. By contrast, in human islets, islet cells are organized in a disorderly manner. However, human $\alpha$ cells also have $\beta$ cells surrounding the blood vessels [43]. Therefore, it is possible to consider the influence of paracrine on pancreatic $\alpha$ cells from pancreatic $\beta$ cells also in human.

Just as insulin from $\beta$ cells suppresses glucagon secretion from $\alpha$ cells, glucagon secretion from pancreatic $\alpha$ cells is autocrinally and paracrinally regulated by various factors secreted by the pancreatic islet $\alpha, \beta$, and $\delta$ cells. GABA, $\mathrm{Zn}^{2+}$, and insulin secreted by pancreatic $\beta$ cells suppress glucagon secretion from $\alpha$ cells. GABA is known as a major inhibitory transmitter in the central nervous system, but has also been shown to be present with high concentrations in the pancreas [44-46]. In $\beta$ cells, GABA is synthesized from glutamine via the action of glutamic acid decarboxylase (GAD) and is released when the decellularization of $\beta$ cells occurs and the intracellular free $\mathrm{Ca}^{2+}$ concentration is increased. In mouse islets and $\alpha$ cell lines ( $\alpha$-TC1-9), GABA released from $\beta$ cells binds to the GABA-A receptors of $\alpha$ cells and suppresses glucagon secretion [47-49]. Additionally, $\mathrm{Zn}^{2+}$ is contained in the insulin granules of pancreatic $\beta$ cells. In the perfused pancreas of rats, glucose-induced $\mathrm{Zn}^{2+}$ secretion from $\beta$ cells suppressed glucagon secretion [50]. However, in some reports that used mouse pancreatic islets, $\mathrm{Zn}^{2+}$ did not suppress glucagon secretion [51]. Furthermore, no changes were observed in glucose-induced glucagon secretion in $\mathrm{Zn}^{2+}$ granule transporter knockout mice [52]. Therefore, the contribution of $\mathrm{Zn}^{2+}$ in regulating glucagon secretion remains controversial. In addition, glucagon exocytosis in $\alpha$ cells is inhibited by juxtacrine via the Ephin subtype A (EphA) of $\beta$ cells and EphA 4/7 receptor of $\alpha$ cells [53]. That is, glucagon secretion from pancreatic $\alpha$ cells is suppressed by paracrine and juxtacrine from pancreatic $\beta$ cells. Somatostatin secreted by $\delta$ cells also suppresses glucagon secretion from $\alpha$ cells similar to that from $\beta$ cells $[54,55]$. Somatostatin receptor (SSTR) subtype 2 is present in $\alpha$ cells which suppresses glucose-induced glucagon secretion by reducing intracellular cAMP levels [32,56,57]. Moreover, glucagon secretion increased in isolated islets of SSTR2 knockout mice [58]. Somatostatin inhibits glucagon secretion in the pancreatic $\alpha$ cell line InR1G9 cells [59]. Moreover, these reports have supported the notion that somatostatin suppresses glucagon secretion from $\alpha$ cells. The suppression of arginine-induced glucagon secretion was observed in systemic somatostatin knockout mice. However, it did not affect basal glucagon secretion [60]. In addition, in rats, the administration of SSTR2-specific antagonists that inhibited insulin secretion with STZ treated mice did not alter blood glucagon levels [61]. That is, somatostatin suppresses glucagon secretion. However, somatostatin alone cannot completely suppress glucagon secretion. In addition, GRs are present in pancreatic $\alpha$ cells [62-64]. Western blot and immunohistological staining confirmed the presence of GRs in human, mouse pancreatic islets and $\alpha$ cell lines ( $\alpha$-TC1-9) [65]. Glucagon secreted from $\alpha$ cells binds to its own GR, promotes its own glucagon secretion via the cAMP-PKA pathways, and up-regulates its own gene expression in human and mouse islets and $\alpha$ cell line ( $\alpha$-TC1-9). In addition, the expression of Gcg mRNA decreased when glucagon receptor 
antagonists were added to mouse islets and $\alpha$-TC1-9 cells [65]. Therefore, glucagon secretion in pancreatic $\alpha$ cells is controlled by other islet cells or themselves, and such mechanism is associated with the pathogenesis of diabetes (Figure 3).

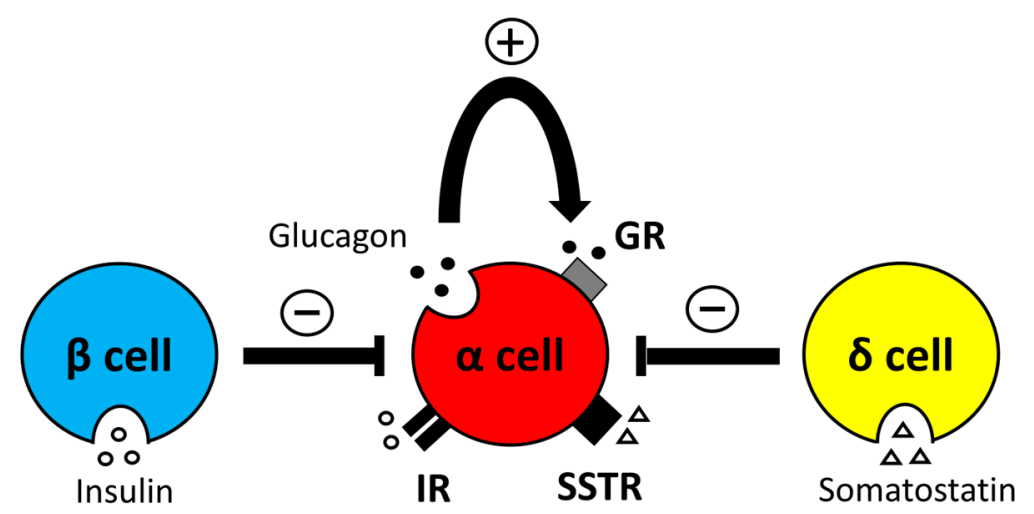

Figure 3. Relationship between islet hormones and glucagon secretion in pancreatic $\alpha$ cells. Insulin, glucagon, and somatostatin subtype 2 receptors are present in $\alpha$ cells. Glucagon secretion in $\alpha$ cells is suppressed by somatostatin and insulin secreted by $\beta$ and $\delta$ cells, respectively. Meanwhile, glucagon secreted by $\alpha$ cells per se enhances glucagon secretion. "+": Enhancement of glucagon secretion. "-": Suppression of glucagon secretion.

\section{Diabetes Therapy Targeting Glucagon}

Currently, there are several different diabetes drugs available worldwide, some of which affect glucagon in various ways and exhibit hypoglycemic action. Glucagon-like peptide-1 (GLP-1) agonist and dipeptidyl peptidase-4 (DPP4) inhibitor, which are incretin-related drugs, suppress glucagon secretion. DPP4 is an enzyme that inhibits GLP-1. When either of these drugs is administered, the concentration of GLP-1 in the blood increases. Administration of GLP-1 suppresses glucagon secretion in patients with type 2 diabetes, as measured using a glucose clamp test [66]. The mechanism by which GLP-1 suppresses glucagon reportedly involves the activation of the cAMP-PKA pathway via the GLP-1 receptors of pancreatic $\alpha$ cells and suppression of voltage-gated N-type Ca channel activity, thereby resulting in the suppression of glucagon secretion [67]. However, this mechanism is controversial, because the GLP-1 receptor is only expressed at low levels in pancreatic $\alpha$ cells. On the other hand, an indirect mechanism in which GLP-1 induces somatostatin secretion from pancreatic $\delta$ cells and suppresses glucagon secretion via the SSTR- 2 of pancreatic $\alpha$ cells has been reported [68]. GLP-1 increases insulin secretion from $\beta$ cells and suppresses glucagon secretion. Therefore, although several mechanisms for the suppression of glucagon secretion by GLP-1 have been reported, the details have not yet been completely elucidated [69]. On the other hand, biguanide has an inhibitory effect on glucagon. Metformin, a member of the biguanide class of antidiabetic drugs, improves insulin resistance by suppressing gluconeogenesis in the liver and promoting glucose uptake in the skeletal muscle. In the liver, metformin suppresses complex I in the mitochondria. The main mechanism of action is considered to be the suppression of gluconeogenesis and release of glucose via the activation of AMP-activated protein kinase resulting from the elevation of AMP concentrations [70]. However, recently it has been reported that glucagon inhibition by metformin results from the elevation of AMP concentration in the liver, which promotes the inhibition of adenylate cyclase via glucagon receptors and suppresses the cAMP-PKA pathway, thereby leading to the suppression of glucose production by glucagon [71]. By contrast, other antidiabetic drugs-sulfonylurea, glinide, and SGLT2 inhibitor are considered to promote glucagon secretion to different extents.

In addition, glucagon receptor antagonists that suppress gluconeogenesis in the liver and lower blood glucose levels have recently been developed. LY2409021 is a low molecular weight compound that is an antagonist to the glucagon receptor. A marked improvement in blood glucose was observed after 12 weeks of administration of this compound to patients with type 2 diabetes [72]. 
However, the development of LY2409021 has recently been stopped due to side effects such as weight gain, blood pressure increase, and fatty liver disease [73,74]. Moreover, neutralizing antibodies against glucagon receptors have recently been developed. REND 2.59, a neutralizing antibody against glucagon receptors, has shown remarkable improvement in blood glucose levels in studies using diabetic model mice [75]. There were no side effects observed with the use of LY2409021, and weight loss as well as improved fatty liver disease were observed [75].

Among various antidiabetic drugs currently available, incretin-related drugs and biguanide are considered to exert a glucagon inhibitory effect, and their mechanism of action has been elucidated. Furthermore, new drugs including glucagon receptor antagonists and neutralizing antibodies are currently under development, and the importance of glucagon in diabetes is increasingly recognized.

\section{Limitations of Pancreatic $\alpha$ Cell Research}

Studies regarding to the glucagon are few compared to those of insulin, and there are two major reasons. First, there is a problem with the glucagon assay system. Conventionally, glucagon is measured by using radioimmunoassay methods with antibodies that recognize the C-terminal structure of glucagon. However, these methods cannot accurately measure glucagon because of the existence of glucagon-like peptides, whose amino acids sequence overlap with glucagon. In particular, glicentin, the C-terminal sequence of which is identical to that of glucagon, causes cross-reaction. However, in recent years, glucagon can be more accurately measured by newly developed methods, i.e., sandwich enzyme-linked immunosorbent assay using antibodies that recognize the C-terminus and $\mathrm{N}$-terminus of glucagon, and liquid chromatography/mass spectrometry (LC/MS/MS). Therefore, the problem seems to be solved (but this is not the case). Second, there is a problem with the material used. In the case of mice and rats used in the experiment, islets cells are mainly composed of $\beta$ cells and $\alpha$ cells by around $80 \%$ and $10 \%$, respectively. Therefore, $\alpha$ cell research is challenging because the number of $\alpha$ cells is much fewer than $\beta$ cells. In addition, although insulin is a relatively stable hormone, glucagon is unstable and rapidly broken down at room temperature. Moreover, most studies analyzing glucagon secretion have used transformed $\alpha$ cell lines, and only a few studies have utilized native $\alpha$ cells, which is attributed to the absence of established methods that isolate pancreatic $\alpha$ cells owing to their unstable viability. Currently, the commonly used $\alpha$ cell lines are InR1G9 [76], HIT T15-G [77], and $\alpha$-TC1 [78] cells. However, the ability of the first two cell lines to mimic native pancreatic $\alpha$ cells is debatable because they were initially derived from insulinomas ( $\beta$ cells). Although $\alpha$-TC1 cells are derived from glucagonomas, glucagon secretion in response to glucose and insulin has been poor because oncogene is constantly expressed; thus, the cells, such as native $\alpha$ cells, are in the growth phase and do not exhibit differentiation characteristics. Therefore, the establishment of new methods for isolating native $\alpha$ cells or a new $\alpha$ cell line with similar properties to native $\alpha$ cells is required in $\alpha$ cell research.

\section{Conclusions}

In type 2 diabetes, glucagon dysregulation is as important as insulin dysregulation. In fact, paradoxical glucagon hypersecretion under hyperglycemic conditions and impaired glucagon secretion under hypoglycemic conditions are commonly observed in diabetes. Therefore, the relationship between insulin and glucagon - the major factors that determine blood glucose level—is important in diabetes research. In recent years, insulin resistance in pancreatic $\alpha$ cells has been proposed; moreover, the relationship between insulin and glucagon has been gaining considerable attention. In insulin-resistant $\alpha$-cell lines, the regulation of glucagon secretion and expression is disturbed. In pancreatic $\alpha$ cell-specific IR knockout mice, increased postprandial plasma glucagon levels and hyperglycemia have been observed. Therefore, insulin resistance in $\alpha$ cells is associated with glucagon dysregulation in diabetes. Although the mechanism underlying cell autonomous dysfunction of $\alpha$ cells has not yet been elucidated, it is believed to be correlated with the pathophysiology of diabetes. 
Therefore, $\alpha$ cell research using native $\alpha$ cells or $\alpha$ cell lines with similar properties to native $\alpha$ cells should be performed for better understanding of the pathophysiology of diabetes.

Here are the final summaries;

1. Type 2 diabetes is considered to be a "bi-hormonal disorder" rather than an "insulin-centric disorder," suggesting that glucagon is as important as insulin. Recently, "glucagonocentric hypothesis", in which glucagon contributes more to increase in blood sugar level than insulin, has attracted attention.

2. Insulin resistance in pancreatic $\alpha$ cells means a state in which the insulin signal of $\alpha$ cells is attenuated. In normal conditions, insulin suppresses the secretion of glucagon from pancreatic $\alpha$ cells. However, when insulin resistance exists in diabetic pancreatic $\alpha$ cells, insulin can no longer suppress glucagon secretion from $\alpha$ cells, which results in hypersecretion of glucagon. Hypothetical paradoxical glucagon hypersecretion observed in diabetes.

3. The molecular mechanism of glucose-regulated glucagon secretion in pancreatic $\alpha$-cells has not yet been elucidated, but the involvement of cAMP, ATP/ADP ratio, and $\mathrm{K}_{\text {ATP }}$ channel has been reported.

4. The new drugs such as glucagon receptor antagonist and neutralizing antibody are currently developing.

5. Glucagon studies have problems with measurement systems and materials. The problem of the measurement system is being solved, but the problem of the material has not been solved yet. Therefore, the establishment of new methods for isolating native $\alpha$ cells or construction of a new $\alpha$ cell line having similar properties with native $\alpha$ cells is required for future $\alpha$ cell research.

Author Contributions: N.H. wrote the manuscript. K.F. and T.K. made important suggestions for the amendments. All authors read and approved the final manuscript.

Funding: This research was supported by The Jikei University Research Fund for Graduate Students (to N.H.). Grant-in-Aid for Scientific Research (C) (18K08491) from the Ministry of Education, Culture, Sports, Science, and Technology of Japan (to K.F.). Grant-in-Aid for Scientific Research (B) (19H03707) from the Ministry of Education, Culture, Sports, Science, and Technology of Japan (to T.K.).

Acknowledgments: The authors would like to thank members of their laboratory for helpful and constructive advice.

Conflicts of Interest: K.F. received honorarium from Sanofi K.K, Merck Sharpe \& Dohme, Taisho Pharmaceutical, Eli Lilly Japan KK, TERUMO Corporation, ARKRAY, Astellas Pharma, AstraZeneca, Nippon Boehringer Ingelheim, Mitsubishi Tanabe Pharma Corporation, Ono Pharmaceutical, Novo Nordisk Pharma, Kissei Pharmaceutical, Sumitomo Dainippon Pharma, Kowa Pharmaceutical, Takeda Pharmaceutical, Daiichi Sankyo, Chugai Pharmaceutical, Abbot Japan, Otsuka Pharmaceutical and Kyowa Hakko Kirin. The funders had no role in the design of the study. The authors declare no other conflict of interest.

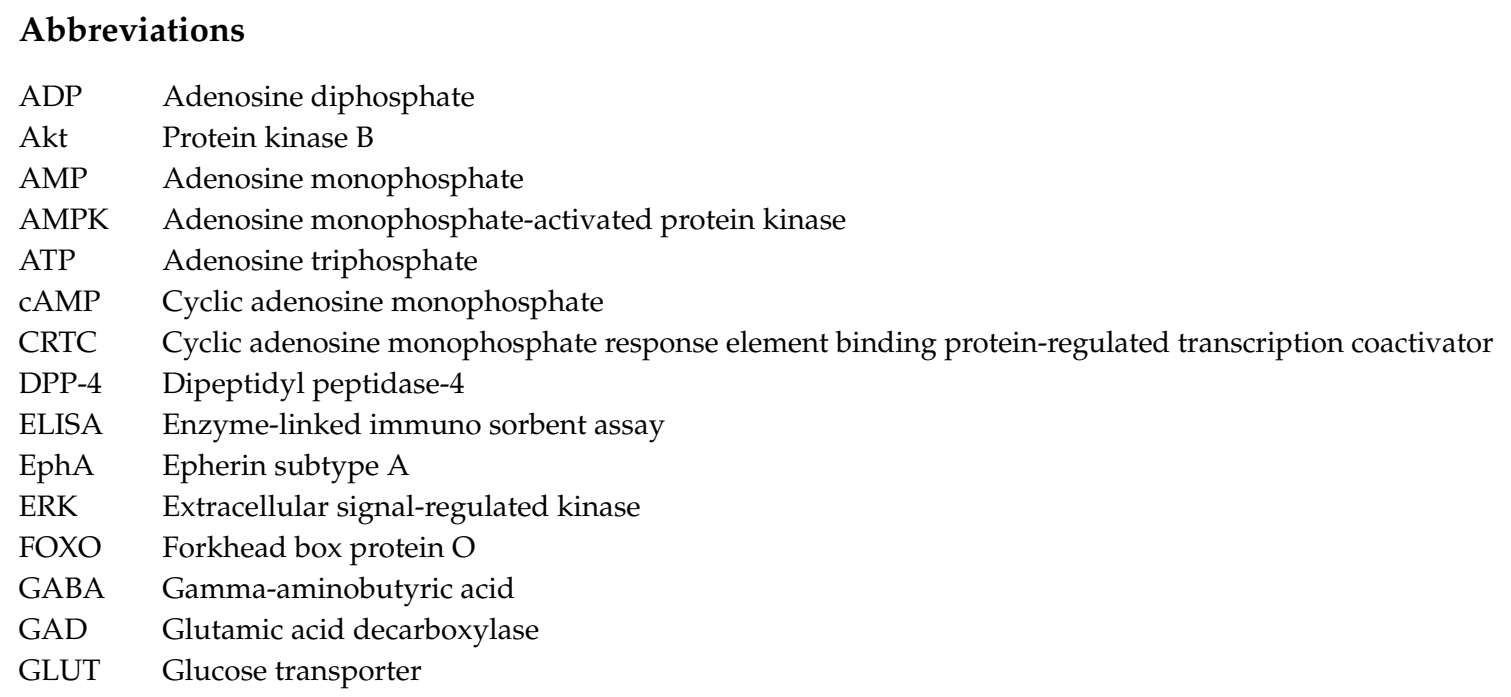




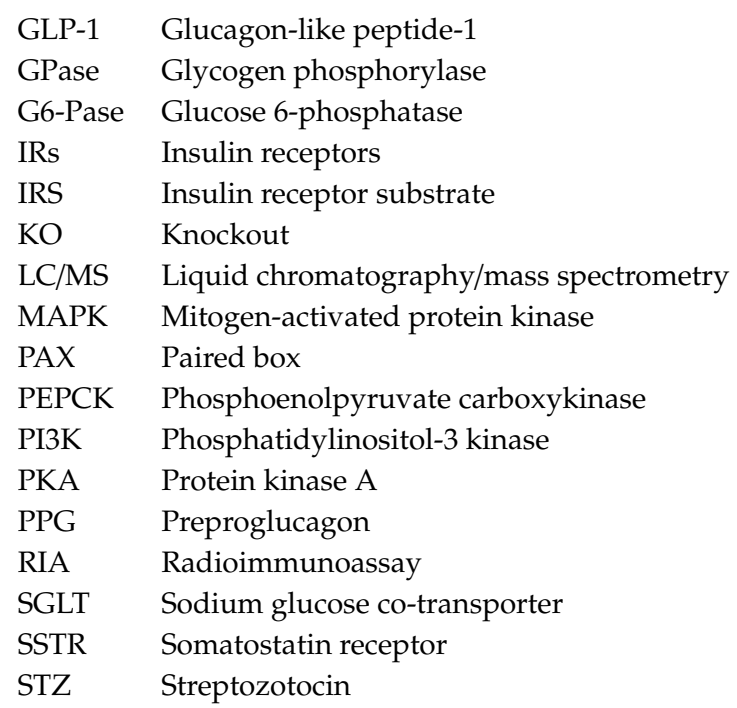

\section{References}

1. DeFronzo, R.A. Pathogenesis of type 2 diabetes mellitus. Med. Clin. North Am. 2004, 88, 787-835. [CrossRef] [PubMed]

2. Banting, F.G.; Best, C.H.; Collip, J.B.; Campbell, W.R.; Fletcher, A.A. Pancreatic extracts in the treatment of diabetes mellitus. Can. Med. Assoc. J. 1922, 12, 141-146. [PubMed]

3. Haeusler, R.A.; McGraw, T.E.; Accili, D. Biochemical and cellular properties of insulin receptor signaling. Nat. Rev. Mol. Cell Biol. 2018, 19, 31-44. [CrossRef] [PubMed]

4. Leto, D.; Saltiel, A.R. Regulation of glucose transport by insulin: Traffic control of GLUT4. Nat. Rev. Mol. Cell Biol. 2012, 13, 383-396. [CrossRef] [PubMed]

5. Thorens, B. GLUT2, glucose sensing and glucose homeostasis. Diabetologia 2015, 58, 221-232. [CrossRef] [PubMed]

6. Kimball, C.P.; Murin, J.R. Aqueous extracts of pancreas III. Some precipitation reactions of insulin. J. Biol. Chem. 1923, 58, 337-346.

7. Liu, Y.; Dentin, R.; Chen, D.; Hedrick, S.; Ravnskjaer, K.; Schenk, S.; Milne, J.; Meyers, D.J.; Cole, P.; Yates, J., III; et al. A fasting inducible switch modulates gluconeogenesis via activator/coactivator exchange. Nature 2008, 456, 269-273. [CrossRef]

8. Ravnskjaer, K.; Hogan, M.F.; Lackey, D.; Tora, L.; Dent, S.Y.; Olefsky, J.; Montminy, M. Glucagon regulates gluconeogenesis through KAT2B-and WDR5-mediated epigenetic effects. J. Clin. Investig. 2013, 123, 4318-4328. [CrossRef] [PubMed]

9. Zhang, L.; Yao, W.; Xia, J.; Wang, T.; Huang, F. Glucagon-induced acetylation of energy-sensing factors in control of hepatic metabolism. Int. J. Mol. Sci. 2019, 20, 1885. [CrossRef]

10. Hancock, A.S.; Du, A.; Liu, J.; Miller, M.; May, C.L. Glucagon deficiency reduces hepatic glucose production and improves glucose tolerance in adult mice. Mol. Endocrinol. 2010, 24, 1605-1614. [CrossRef]

11. Lee, Y.; Wang, M.Y.; Du, X.Q.; Charron, M.J.; Unger, R.H. Glucagon receptor knockout prevents insulin-deficient type 1 diabetes in mice. Diabetes 2011, 60, 391-397. [CrossRef]

12. Lee, Y.; Berglund, E.D.; Wang, M.Y.; Fu, X.; Yu, X.; Charron, M.J.; Burgess, S.C.; Unger, R.H. Metabolic manifestations of insulin deficiency do not occur without glucagon action. Proc. Natl. Acad. Sci. USA 2012, 109, 14972-14976. [CrossRef]

13. Unger, R.H.; Cherrington, A.D. Glucagonocentric restructuring of diabetes: A pathophysiologic and therapeutic makeover. J. Clin. Investig. 2012, 122, 4-12. [CrossRef]

14. Maruyama, H.; Tominaga, M.; Bolli, G.; Orci, L.; Unger, R.H. The alpha cell response to glucose change during perfusion of anti-insulin serum in pancreas isolated from normal rats. Diabetologia 1985, 28, 836-840. [CrossRef] 
15. Kawamori, D.; Kurpad, A.J.; Hu, J.; Liew, C.W.; Hih, J.L.; Ford, E.L.; Herrera, P.L.; Polonsky, K.S.; McGuinness, O.P.; Kulkarni, R.N. Insulin signaling in alpha cells modulates glucagon secretion in vivo. Cell Metab. 2009, 9, 351-361. [CrossRef]

16. Heimberg, H.; De Vos, A.; Pipeleers, D.; Thorens, B.; Schuit, F. Differences in glucose transporter gene expression between rat pancreatic alpha- and beta- cells are correlated to differences in glucose transport but not in glucose utilization. J. Biol. Chem. 1995, 270, 8971-8975. [CrossRef]

17. Bonner, C.; Kerr-Conte, J.; Gmyr, V.; Queniat, G.; Moerman, E.; Thevenet, J.; Beaucamps, C.; Delalleau, N.; Popescu, I.; Malaisse, W.J.; et al. Inhibition of the glucose transporter SGLT2 with dapagliflozin in pancreatic alpha cells triggers glucagon secretion. Nat. Med. 2015, 21, 512-517. [CrossRef]

18. Benner, C.; van der Meulen, T.; Caceres, E.; Tigyi, K.; Donaldson, C.J.; Huising, M.O. The transcriptional landscape of mouse beta cells compared to human beta cells reveals notable species differences in long non-coding RNA and protein-coding gene expression. BMC. Genom. 2014, 15, 620. [CrossRef]

19. Blodgett, D.M.; Nowosielska, A.; Afik, S.; Pechhold, S.; Cura, A.J.; Kennedy, N.J.; Kim, S.; Kucukural, A.; Davis, R.J.; Kent, S.C.; et al. Novel observations from next-generation RNA sequencing of highly purified human adult and fetal islet cell subsets. Diabetes 2015, 64, 3172-3181. [CrossRef]

20. Suga, T.; Kikuchi, O.; Kobayashi, M.; Matsui, S.; Yokota-Hashimoto, H.; Wada, E.; Kohno, D.; Sasaki, T.; Takeuchi, K.; Kakizaki, S.; et al. SGLT1 in pancreatic $\alpha$ cells regulates glucagon secretion in mice, possibly explaining the distinct effects of SGLT2 inhibitors on plasma glucagon levels. Mol. Metab. 2019, 19, 1-12. [CrossRef]

21. Zhang, Q.; Ramracheya, R.; Lahmann, C.; Tarasov, A.; Bengtsson, M.; Braha, O.; Braun, M.; Brereton, M.; Collins, S.; Galvanovskis, J.; et al. Role of KATP channels in glucose-regulated glucagon secretion and impaired counterregulation in type 2 diabetes. Cell Metab. 2013, 18, 871-882. [CrossRef]

22. Zhang, Q.; Chibalina, M.V.; Bengtsson, M.; Groschner, L.N.; Ramracheya, R.; Rorsman, N.J.; Leiss, V.; Nassar, M.A.; Welling, A.; Gribble, F.M.; et al. Na+ current properties in islet alpha- and beta- cells reflect cell-specific Scn3a and Scn9a expression. J. Physiol. 2014, 592, 4677-4696. [CrossRef]

23. Barg, S.; Galvanovskis, J.; Göpel, S.O.; Rorsman, P.; Eliasson, L. Tight Coupling Between Electrical Activity and Exocytosis in Mouse Glucagon-Secreting $\alpha$-Cells. Diabetes 2000, 49, 1500-1510. [CrossRef]

24. Yu, Q.; Shuai, H.; Ahooghalandari, P.; Gylfe, E.; Tengholm, A. Glucose controls glucagon secretion by directly modulating cAMP in alpha cells. Diabetologia 2019, 62, 1212-1224. [CrossRef]

25. Knudsen, J.G.; Hamilton, A.; Ramracheya, R.; Tarasov, A.I.; Brereton, M.; Haythorne, E.; Chibalina, M.V.; Spegel, P.; Mulder, H.; Zhang, Q.; et al. Dysregulation of glucagon secretion by hyperglycemia-induced sodium-dependent reduction of ATP production. Cell Metab. 2019, 2019. 29, 430-442. [CrossRef]

26. Gerich, J.E.; Langlois, M.; Noacco, C.; Karam, J.H.; Forsham, P.H. Lack of glucagon response to hypoglycemia in diabetes: Evidence for an intrinsic pancreatic alpha cell defect. Science 1973, 182, 171-173. [CrossRef]

27. Unger, R.H.; Orci, L. The essential role of glucagon in the pathogenesis of diabetes mellitus. Lancet 1975, 1, 14-16. [CrossRef]

28. Cryer, P.E. Mechanisms of hypoglycemia-associated autonomic failure in diabetes. N. Engl. J. Med. 2013, 369, 362-372. [CrossRef]

29. Reaven, G. The metabolic syndrome or the insulin resistance syndrome? Different names, different concepts, and different goals. Endocrinol. Metab. Clin. North Am. 2004, 33, 283-303. [CrossRef]

30. Braaten, J.T.; Faloona, G.R.; Unger, R.H. The Effect of Insulin on the Alpha-Cell Response to Hyperglycemia in Long-Standing Alloxan Diabetes. J. Clin. Investig. 1974, 53, 1017-1021. [CrossRef]

31. Gromada, J.; Ma, X.; Høy, M.; Bokvist, K.; Salehi, A.; Berggren, P.O.; Rorsman, P. ATP-Sensitive K ${ }^{+}$ Channel-Dependent Regulation of Glucagon Release and Electrical Activity by Glucose in Wild-Type and SUR1-/- Mouse $\alpha$-Cells. Diabetes 2004, 53, S181-S189. [CrossRef]

32. Briant, L.J.B.; Reinbothe, T.M.; Spiliotis, I.; Miranda, C.; Rodriguez, B.; Rorsman, P. Delta-cells and beta-cells are electrically coupled and regulate alpha-cell activity via somatostatin. J. Physiol. 2018, 596, 197-215. [CrossRef]

33. Elliott, A.D.; Ustione, A.; Piston, D.W. Somatostatin and insulin mediate glucose-inhibited glucagon secretion in the pancreatic alpha-cell by lowering cAMP. Am. J. Physiol. Endocrinol. Metab. 2015, 308, E130-E143. [CrossRef]

34. Franklin, I.; Gromada, J.; Gjinovci, A.; Theander, S.; Wollheim, C.B. $\beta$-Cell secretory products activate $\alpha$-Cell ATP-dependent potassium channels to inhibit glucagon release. Diabetes 2005, 54, 1808-1815. [CrossRef] 
35. Leung, Y.M.; Ahmed, I.; Sheu, L.; Gao, X.; Hara, M.; Tsushima, R.G.; Diamant, N.E.; Gaisano, H.Y. Insulin regulates islet alpha-cell function by reducing KATP channel sensitivity to adenosine $5^{\prime}$-triphosphate inhibition. Endocrinology 2006, 147, 2155-2162. [CrossRef]

36. Xu, E.; Kumar, M.; Zhang, Y.; Ju, W.; Obata, T.; Zhang, N.; Liu, S.; Wendt, A.; Deng, S.; Ebina, Y.; et al. Intra-islet insulin suppresses glucagon release via GABA-GABAA receptor system. Cell Metab. 2006, 3, 47-58. [CrossRef]

37. Katsura, T.; Kawamori, D.; Aida, E.; Matsuoka, T.A.; Shimomura, I. Glucotoxicity induces abnormal glucagon secretion through impaired insulin signaling in InR1G cells. PLoS ONE 2017, 12, e0176271. [CrossRef]

38. Lee, Y.; Berglund, E.D.; Yu, X.; Wang, M.Y.; Evans, M.R.; Scherer, P.E.; Holland, W.L.; Charron, M.J.; Roth, M.G.; Unger, R.H. Hyperglycemia in rodent models of type 2 diabetes requires insulin-resistant alpha cells. Proc. Natl. Acad. Sci. USA 2014, 111, 13217-13222. [CrossRef]

39. Piro, S.; Maniscalchi, E.T.; Monello, A.; Andini, G.; Mascali, L.G.; Rabuazzo, A.M.; Purrello, F. Palmitate affects insulin receptor phosphorylation and intracellular insulin signal in a pancreatic a-cell line. Endocrinology 2010, 151, 4197-4206. [CrossRef]

40. Diao, J.; Asghar, Z.; Chan, C.B.; Wheeler, M.B. Glucose-regulated glucagon secretion requires insulin receptor expression in pancreatic alpha-cells. J. Biol. Chem. 2005, 280, 33487-33496. [CrossRef]

41. Gromada, J.; Franklin, I.; Wollheim, C.B. Alpha-cells of the endocrine pancreas: 35 years of research but the enigma remains. Endocr. Rev. 2007, 28, 84-116. [CrossRef]

42. Stagner, J.I.; Samols, E. Retrograde perfusion as a model for testing the relative effects of glucose versus insulin on the A cell. J. Clin. Investig. 1986, 77, 1034-1037. [CrossRef]

43. Bosco, D.; Armanet, M.; Morel, P.; Niclauss, N.; Sgroi, A.; Muller, Y.D.; Giovannoni, L.; Parnaud, G.; Berney, T. Unique arrangement of alpha- and beta-cells in human islets of Langerhans. Diabetes 2010, 59, 1202-1210. [CrossRef]

44. Okada, Y.; Taniguchi, H.; Schimada, C. High concentration of GABA and high glutamate decarboxylase activity in rat pancreatic islets and human insulinoma. Science 1976, 194, 620-622. [CrossRef]

45. Briel, G.; Gylfe, E.; Hellman, B.; Neuhoff, V. Microdetermination of free amino acids in pancreatic islets isolated from obese-hyperglycemic mice. Acta Physiol. Scand. 1972, 84, 247-253. [CrossRef]

46. Gylfe, E.; Hellman, B. Role of glucose as a regulator and precursor of amino acids in the pancreatic beta-cells. Endocrinology 1974, 94, 1150-1156. [CrossRef]

47. Reetz, A.; Solimena, M.; Matteoli, M.; Folli, F.; Takei, K.; De Camilli, P. GABA and pancreatic beta-cells: Colocalization of glutamic acid decarboxylase (GAD) and GABA with synaptic-like microvesicles suggests their role in GABA storage and secretion. Embo J. 1991, 10, 1275-1284. [CrossRef]

48. Rorsman, P.; Berggren, P.O.; Bokvist, K.; Ericson, H.; Mohler, H.; Ostenson, C.G.; Smith, P.A. Glucose-inhibition of glucagon secretion involves activation of GABAA-receptor chloride channels. Nature 1989, 341, 233-236. [CrossRef]

49. Bailey, S.J.; Ravier, M.A.; Rutter, G.A. Glucose-dependent regulation of gamma-aminobutyric acid (GABA A) receptor expression in mouse pancreatic islet alpha-cells. Diabetes 2007, 56, 320-327. [CrossRef]

50. Ishihara, H.; Maechler, P.; Gjinovci, A.; Herrera, P.L.; Wollheim, C.B. Islet beta-cell secretion determines glucagon release from neighbouring alpha-cells. Nat. Cell Biol. 2003, 5, 330-335. [CrossRef]

51. Ravier, M.A.; Rutter, G.A. Glucose or insulin, but not zinc ions, inhibit glucagon secretion from mouse pancreatic alpha-cells. Diabetes 2005, 54, 1789-1797. [CrossRef]

52. Nicolson, T.J.; Bellomo, E.A.; Wijesekara, N.; Loder, M.K.; Baldwin, J.M.; Gyulkhandanyan, A.V.; Koshkin, V.; Tarasov, A.I.; Carzaniga, R.; Kronenberger, K.; et al. Insulin storage and glucose homeostasis in mice null for the granule zinc transporter ZnT8 and studies of the type 2 diabetes-associated variants. Diabetes 2009, 58, 2070-2083. [CrossRef]

53. Hutchens, T.; Piston, D.W. EphA 4 receptor forward signaling inhibits glucagon secretion from $\alpha$ cells. Diabetes 2015, 64, 3839-3851. [CrossRef]

54. Gerich, J.E.; Langlois, M.; Noacco, C.; Lorenzi, M.; Karam, J.H.; Korsham, P.H. Comparison of the suppressive effects of elevated plasma glucose and free fatty acid levels on glucagon secretion in normal and insulin-dependent diabetic subjects. Evidence for selective alpha-cell insensitivity to glucose in diabetes mellitus. J. Clin. Investig. 1976, 58, 320-325. [CrossRef]

55. Sakurai, H.; Dobbs, R.; Unger, R.H. Somatostatin-induced changes in insulin and glucagon secretion in normal and diabetic dogs. J. Clin. Investig. 1974, 54, 1395-1402. [CrossRef] 
56. Cejvan, K.; Coy, D.H.; Efendic, S. Intra-islet somatostatin regulates glucagon release via type 2 somatostatin receptors in rats. Diabetes 2003, 52, 1176-1181. [CrossRef]

57. Starke, A.; Imamura, T.; Unger, R.H. Relationship of glucagon suppression by insulin and somatostatin to the ambient glucose concentration. J. Clin. Investig. 1987, 79, 20-24. [CrossRef]

58. Strowski, M.Z.; Parmar, R.M.; Blake, A.D.; Schaeffer, J.M. Somatostatin inhibits insulin and glucagon secretion via two receptor subtypes: An in vitro study of pancreatic islets from somatostatin receptor 2 knockout mice. Endocrinology 2000, 141, 111-117. [CrossRef]

59. Chen, L.; Philippe, J.; Unger, R.H. Glucagon responses of isolated alpha cells to glucose, insulin, somatostatin, and leptin. Endocr. Pr. 2011, 17, 819-825. [CrossRef]

60. Hauge-Evans, A.C.; King, A.J.; Carmignac, D.; Richardson, C.C.; Robinson, I.C.; Low, M.J.; Christie, M.R.; Persaud, S.J.; Jones, P.M. Somatostatin secreted by islet delta-cells fulfills multiple roles as a paracrine regulator of islet function. Diabetes 2009, 58, 403-411. [CrossRef]

61. Yue, J.T.; Burdett, E.; Coy, D.H.; Giacca, A.; Efendic, S.; Vranic, M. Somatostatin receptor type 2 antagonism improves glucagon and corticosterone counterregulatory responses to hypoglycemia in streptozotocin-induced diabetic rats. Diabetes 2012, 61, 197-207. [CrossRef]

62. Ma, X.; Zhang, Y.; Gromada, J.; Sewing, S.; Berggren, P.O.; Buschard, K.; Salehi, A.; Vikman, J.; Rorsman, P.; Eliasson, L. Glucagon stimulates exocytosis in mouse and rat pancreatic alpha-cells by binding to glucagon receptors. Mol. Endocrinol. 2005, 19, 198-212. [CrossRef]

63. Tian, G.; Sandler, S.; Gylfe, E.; Tengholm, A. Glucose- and hormone-induced cAMP oscillations in alpha- and beta-cells within intact pancreatic islets. Diabetes 2011, 60, 1535-1543. [CrossRef]

64. Liu, Z.; Kim, W.; Chen, Z.; Shin, Y.K.; Carlson, O.D.; Fiori, J.L.; Xin, L.; Napora, J.K.; Short, R.; Odetunde, J.O.; et al. Insulin and glucagon regulate pancreatic alpha-cell proliferation. Plos ONE 2011, 6, e16096.

65. Leibiger, B.; Moede, T.; Muhandiramlage, T.P.; Kaiser, D.; Vaca Sanchez, P.; Leibiger, I.B.; Berggren, P.O. Glucagon regulates its own synthesis by autocrine signaling. Proc. Natl. Acad. Sci. USA 2012, 109, 20925-20930. [CrossRef]

66. Hare, K.J.; Vilsboll, T.; Asmar, M.; Deacon, C.F.; Knop, F.K.; Holst, J.J. The glucagonostatic and insulinotropic effects of glucagon-like peptide 1 contribute equally to its glucose-lowering action. Diabetes 2010, 59, 1765-1770. [CrossRef]

67. De Marinis, Y.Z.; Salehi, A.; Ward, C.E.; Zhang, Q.; Abdulkader, F.; Bengtsson, M.; Braha, O.; Braun, M.; Ramracheya, R.; Amisten, S.; et al. GLP-1 inhibits and adrenaline stimulates glucagon release by differential modulation of N- and L-type $\mathrm{Ca}^{2+}$ channel-dependent exocytosis. Cell Metab. 2010, 11, 543-553. [CrossRef]

68. De Heer, J.; Rasmussen, C.; Coy, D.H.; Holst, J.J. Glucagon-like peptide-1, but not glucose-dependent insulinotropic peptide, inhibits glucagon secretion via somatostatin (receptor subtype 2) in the perfused rat pancreas. Diabetologia 2008, 51, 2263-2270. [CrossRef]

69. Campbell, J.E.; Drucker, D.J. Pharmacology, physiology, and mechanisms of incretin hormone action. Cell Metab. 2013, 17, 818-837. [CrossRef]

70. Zhou, G.; Myers, R.; Li, Y.; Chen, Y.; Shen, X.; Fenyk-Melody, J.; Wu, M.; Ventre, J.; Doebber, T.; Fujii, N.; et al. Role of AMP-activated protein kinase in mechanism of metformin action. J. Clin. Investig. 2001, 108, 1167-1174. [CrossRef]

71. Miller, R.A.; Chu, Q.; Xie, J.; Foretz, M.; Viollet, B.; Birnbaum, M.J. Biguanides suppress hepatic glucagon signalling by decreasing production of cyclic AMP. Nature 2014, 494, 256-260. [CrossRef]

72. Kazda, C.M.; Ding, Y.; Kelly, R.P.; Garhyan, P.; Shi, C.; Lim, C.N.; Fu, H.; Watson, D.E.; Lewin, A.J.; Landschulz, W.H.; et al. Response to comment on kazda et al. evaluation of efficacy and safety of the glucagon receptor antagonist ly2409021 in patients with type 2 diabetes: 12- and 24-week phase 2 studies. Diabetes Care 2016, 39, 1241-1249. [CrossRef]

73. Kazda, C.M.; Frias, J.; Foga, I.; Cui, X.; Guzman, C.B.; Garhyan, P.; Heilmann, C.; Yang, J.A.; Hardy, T.A. Treatment with the glucagon receptor antagonist LY2409021 increases ambulatory blood pressure in patients with type 2 diabetes. Diabetes Obes. Metab. 2017, 19, 1071-1077. [CrossRef]

74. Guzman, C.B.; Zhang, X.M.; Liu, R.; Regev, A.; Shankar, S.; Garhyan, P.; Pillai, S.G.; Kazda, C.; Chalasani, N.; Hardy, T.A. Treatment with LY2409021, a glucagon receptor antagonist, increases liver fat in patients with type 2 diabetes. Diabetes Obes. Metab. 2017, 19, 1521-1528. [CrossRef] 
75. Sharma, A.X.; Quittner-Strom, E.B.; Lee, Y.; Johnson, J.A.; Martin, S.A.; Yu, X.; Li, J.; Lu, J.; Cai, Z.; Chen, S.; et al. Glucagon receptor antagonism improves glucose metabolism and cardiac function by promoting amp-mediated protein kinase in diabetic mice. Cell Rep. 2018, 22, 1760-1773. [CrossRef]

76. Takaki, R.; Ono, J.; Nakamura, M.; Yokogawa, Y.; Kumae, S.; Hiraoka, T.; Yamaguchi, K.; Hamaguchi, K.; Uchida, S. Isolation of glucagon-secreting cell lines by cloning insulinoma cells. In Vitro Cell Dev. Biol. 1986, 22, 120-126. [CrossRef]

77. Shennan, K.I.; Holst, J.J.; Docherty, K. Proglucagon expression, posttranslational processing and secretion in SV40-transformed islet cells. Mol. Cell Endocrinol. 1989, 67, 93-99. [CrossRef]

78. Hamaguchi, K.; Leiter, E.H. Comparison of cytokine effects on mouse pancreatic alpha-cell and beta-cell lines. Viability, secretory function, and MHC antigen expression. Diabetes 1990, 39, 415-425. [CrossRef]

(C) 2019 by the authors. Licensee MDPI, Basel, Switzerland. This article is an open access article distributed under the terms and conditions of the Creative Commons Attribution (CC BY) license (http://creativecommons.org/licenses/by/4.0/). 